\title{
Penguatan Kelembagaan MPR dalam Sistem Ketatanegaran Negara Republik Indonesia
}

\author{
Strengthening of Institutional MPR in the Constitutional System of the \\ Republic of Indonesia
}

\section{Galang Asmara}

Fakultas Hukum Universitas Mataram

Jln. Majapahit 62, Mataram, Nusa Tenggara Barat, Indonesia.

Tel./Fax:+62370-633035E-mail: galang_alkawoi@yahoo.com

Submitted: Nov 7, 2015; Reviewed: Nov 28, 2015; Accepted: Dec 7, 2015

\begin{abstract}
The 1945 amendement were made in the sessions of the Assembly 1999-2000 has revolutionized state system of Indonesia, including concerning the status and function of state institutions. People's Consultative Assembly (MPR) as one of the state institutions that are still maintained until today including experiencing many changes. Among these changes are related to the position that is no longer as the highest state institution, no longer authorized to elect the President and Vice President are usually done every 5 years. MPR also no longer given the power to establish the Lines of State Policy (GBHN) and others. This paper examines and discusses the efforts to strengthen the Assembly as a state institution in the constitutional system of the Republic of Indonesiai. The method used in studying it is a normative law research by using statute aproach and conceptual aproach. Based on the results of the research, we concluded that efforts be made to strengthen the institutional MPR in the constitutional system of the Republic of Indonesia, among others are: (1) reconstruct an understanding of the position of the Assembly in the state system of the Republic of Indonesia; (2) MPR should be entitled to request and assess the performance of state institutions; (3) MPR also should be given the authority to judge the laws issued by institutions which carry out the Constitution, whether in accordance with the Constitution; (4) The Assembly should be given the authority to make the outlines of state policy $(G B H N)$.
\end{abstract}

Keywords: Checks and Balances; Constitutional System; Institutional Strengthening

Abstrak: Perubahan UUD 1945 yang dilakukan dalam sidang-sidang MPR 1999-2000 telah merombak sistem ketatanegaraan Indonesia, termasuk menyangkut kedudukan dan fungsi lembaga-lembaga negara. MPR sebagai salah satu lembaga negara yang walau masih dipertahankan sampai saat ini, namun termasuk yang mengalami banyak perubahan. Di antara perubahan tersebut adalah terkait dengan kedudukannya yang tidak lagi sebagai lembaga tertinggi negara, tidak lagi berwenang memilih Presiden dan Wakil Presiden yang biasa dilakukan setiap 5 tahun sekali. MPR juga tidak lagi diberi kekuasaan untuk menetapkan GBHN, dan lain-lain. Tulisan ini mengkaji tentang upaya penguatan MPR tersebut sebagai lembaga negara dalam sistem ketatanegaraan RI. Metode yang 
digunakan dalam menganalisis isu tesebut adalah metode penelitian hukum normatif dengan pendekatan perundang-undangan (statute aproach) dan pendekatan konsep (conceptual aproach). Dari pengkajian disimpulkan bahwa upaya-upaya yang dapat dilakukan untuk memperkuat kelembagaan MPR dalam Sistem Ketatanegara Republik Indonesia antara lain adalah: (1) Merekonstruksi (meluruskan) pemahaman (persepsi) tentang kedudukan MPR dalam sistem ketatanegaraan RI; (2) MPR hendaknya berhak untuk meminta dan menilai kinerja lembaga-lembaga negara; (3) MPR juga hendaknya diberi kewenangan untuk menilai produk hukum yang dikeluarkan oleh lembaga-lembaga yang melaksanakan UUD apakah sesuai dengan kemauan UUD; (4) MPR hendaknya diberikan kewenangan untuk membuat GBHN.

Kata Kunci: Checks and Balances; Sistem Ketatanegaraan; Penguatan Kelembagaan

\section{PENDAHULUAN}

Salah satu lembaga negara yang sejak awal kemerdekaan tetap dipertahankan dalam sistem ketatanegaraan hingga kini adalah Majelis Permusyawaratan Rakyat (MPR). Dahulu berdasarkan UUD 1945 yang belum diubah dikenal ada 6 (enam) lembaga negara, yakni Majelis Permusyawaratan Rakyat (MPR), Dewan Perwakilan Rakyat (DPR), Presiden, Dewan Pertimbangan Agung (DPA), Badan Pemeriksa Keuangan (BPK), dan Mahkamah Agung (MA).

Dari 6 (enam) lembaga negara tersebut, MPR dapat dikatakan sebagai satusatunya lembaga negara hasil kreasi bangsa Indonesia sendiri, karena 5 (lima) lembaga negara yang lainnya diadopsi dari lembagalembaga pemerintahan yang ada di zaman Hindia Belanda. Lembaga Kepresidenan (Presiden) merupakan penjelmaan dari lembaga Pemerintahan Hindia Belanda yang pada waktu itu disebut Gouvenuur Generaal. Dewan Perwakilan Rakyat (DPR) merupakan penjelmaan dari Volksraad, Mahkamah Agung (MA) merupakan penjelmaan dari Hogeraad. Badan Pemeriksa Keuangan (BPK) adalah lembaga negara yang diadopsi dari lembaga pemerintahan di zaman Hindia Belanda yang disebut Raad van Rekenkamer.
Sementara Dewan Pertimbangan Agung (DPA) adalah lembaga pemerintahan di zaman Hindia Belanda yang disebut Raad van Nederlandsche Indie yang ada di Batavia atau Raad van State yang ada di negeri Belanda. ${ }^{1}$

Dari 6 (enam) lembaga negara tersebut, 5 (lima) di antaranya tetap dipertahankan termasuk MPR. Sedangkan satu diantaranya, yakni DPA dihapus ketika terjadi perubahan UUD 1945 keempat, tahun 2002. Sedangkan MPR yang kemudian dianggap mempunyai kedudukan yang tertinggi tidak ada contoh sebelumnya, kecuali yang ada di lingkungan negara-negara komunis yang menerapkan sistem partai tunggal di mana kedaulatan rakyat disalurkan ke dalam pelembagaan Mejelis Rakyat yang tertinggi (supreme people's council) seperti di Uni Sovyet, di Republik Rakyat Cina dan lain-lain. ${ }^{2}$

Berdasarkan ketentuan UUD 1945 sebelum diubah, MPR disebut sebagai lembaga tertinggi negara, ${ }^{3}$ pelaksana sepenuhnya kedaulatan rakyat dan diberi kekuasaan se-

\footnotetext{
Lihat uraian Jimly Asshidiqie. (2005). Format Kelembagaan Negara dan Pergeseran Kekuasaan dalam UUD 1945. Yogyakarta: FH UII Press, hlm. 37 Ibid.

Simak Penjelasan UUD 1945 sebelum diamendemen.
} 
bagai berikut: 1) Menetapkan UUD; (Pasal 3 ayat (2); 2) Menetapkan Garis-Garis Besar Haluan Negara; (Pasal 3 ayat (2); 3) Memilih Presiden dan Wakil Presiden; (Pasal 6 ayat (2); dan 4) Mengubah UUD (Pasal 37 ayat (1).

Setelah UUD 1945 diamendemen, MPR tidak lagi menjadi lembaga tertinggi negara pemegang sepenuhnya kedaulatan rakyat. ${ }^{4}$ Beberapa kewenangannya juga dipangkas seperti: MPR tidak lagi berwenang mengangkat Presiden dan Wakil Pesiden yang dahulunya dilakukan setiap 5 tahun sekali, MPR juga tidak lagi dapat menilai pertanggungjawaban Presiden di setiap akhir masa jabatannya. MPR tidak lagi dapat menetapkan Garis-garis Besar Haluan Negara dan ketetapan-ketetapan lainnya.

Kekuasaan MPR berdasarkan UUD 1945 setelah amendemen adalah: 1) Mengubah dan menetapkan Undang-Undang Dasar 1945 (Pasal 3 ayat 1 Perubahan III UUD 1945); 2) Melantik Presiden dan Wakil Presiden (Pasal 3 ayat 2 Perubahan III UUD 1945); 3) Dapat memberhentikan Presiden dan/atau Wakil Presiden dalam masa jabatannya menurut UUD (Pasal 3 ayat 3 Perubahan III dan IV UUD 1945); dan 4) Memilih Presiden atau Wakil Presiden pengganti, jika Presiden dan Wakil Presiden mangkat, berhenti, diberhentikan, atau tidak dapat melakukan kewajibannya dalam masa jabatannya secara bersamaan (Pasal 8 ayat 3 Perubahan III UUD 1945).

4 Jimly Asshiddiqie, Sengketa Kewenangan Konstitusional Lembaga Negara, KonPress, hlm.83. Bandingkan dengan Jimly Asshiddiqie, "Struktur Ketatanegaraan Indonesia Setelah Perubahan Keempat UUD Tahun 1945", http://www.lfip.org/ english/pdf/bali-seminar/Struktur\%20Ketatanegaraan\%20RI\%20-\%20Jimly\%20Asshiddiqie.pdf, hlm. 14. (diunduh 5 Oktober 2015).
Dengan perubahan tersebut, MPR seolah-olah hanya merupakan lembaga negara yang tak banyak berarti dalam kehidupan bernegara sehari-hari. Menurut Warsito, MPR pasca amendemen UUD 1945, praktis hanya menjalankan tugas rutinitas lima tahunan sekali, yaitu, melantik Presiden dan/atau Wakil Presiden. Tugas seremonial kenegaraan ini membutuhkan waktu tidak kurang dan tidak lebih hanya satu setengah jam. ${ }^{5}$ Jadi, MPR praktis ibarat kerakap tumbuh di batu, hidup segan mati tak mau, atau seperti penumpang pesawat yang disuruh duduk di dekat pintu darurat yang akan berfungsi manakala pesawat dalam keadaan bahaya.

Berdasarkan kenyataan tersebut, maka banyak pihak yang menganggap kalau MPR kini kedudukannya melemah atau dalam istilah Warsito 6 "lintuh" tidak lagi seperti ketika zaman Orde Lama atau Orde Baru atau sebelum UUD 1945.7 Karena kedudukannya yang demikian, ada pihak yang bahkan mengusulkan agar institusi MPR dibubarkan dan diganti menjadi badan ad-hoc yang dapat dibentuk ketika ada peristiwa yang menyebabkan keberadaan MPR menjadi wajib. Peristiwa tersebut antara lain pengangkatan dan/atau pemberhentian presiden dan/atau wakil presiden dan menetapkan perubahan Undang-Undang Dasar. ${ }^{8}$

5 Lihat pendapat Warsito, "Kedudukan MPR", dikutip pada laman website: http://warsito-bicara. blogspot.co.id/ 2008/09/kedudukan-mpr.html, Diunduh 5 Nopember 2015.

Ibid

Eko Riyadi. (2012). "Reposisi Majelis Permusyawaratan Rakyat (MPR) dan Implikasinya Terhadap Kedudukan Tap MPR/S Pasca Amendemen UUD 1945". Majalah Supremasi Hukum, Vol. 1, No. 1, Juni 2012, Fakultas Syari'ah dan Hukum, UIN Sunan Kalijaga, hlm. 212.

$8 \quad$ Ibid. 
Beranjak dari konstruksi tersebut, maka perlu diupayakan agar MPR mempunyai kedudukan dan fungsi yang kuat. Setidak-tidaknya tidak dianggap sebagai lembaga negara yang lemah dan tak banyak berfungsi. Dalam hubungan itu, perlu kiranya dikaji tentang upaya apa saja yang harus dilakukan untuk memperkuat kelembagaan MPR dalam sistem ketatanegaraan Republik Indonesia. Melalui tulisan ini akan dibahas tentang upaya apa saja yang perlu dilakukan untuk memerkuat kelembagaan MPR dalam sistem ketatanegaraan RI. Dengan demikian, permasalahan yang akan dibahas dalam tulisan ini adalah upaya apa saja yang perlu dilakukan untuk memerkuat kelembagaan MPR dalam sistem ketatanegaraan RI.

\section{METODE}

Untuk mengkaji dan membahas permasalahan tersebut, digunakan penelitian hukum normatif (doctrinal research) dengan menggunakan pendekatan perundang-undangan (statute aproach) dan pendekatan konseptual (conceptual aproach).

\section{ANALISIS DAN PEMBAHASAN}

Kedudukan dan Kekuasaan MPR Sebelum dan Sesudah Perubahan UUD 1945

Seperti diungkapkan sebelumnya, bahwa menurut sistem ketatanegaraan RI berdasarkan UUD 1945 sebelum diubah, MPR disebut sebagai lembaga tertinggi negara, artinya MPR diberi kedudukan lebih tinggi dari lembaga negara yang lain yakni DPR, Presiden, MA, BPK dan DPA. Sehingga kelima lembaga negara yang lain tersebut disebut sebagai Lembaga Tinggi Negara sedangkan MPR disebut sebagai Lembaga Tertinggi
Negara. ${ }^{9}$ Menurut Muhammad Ridwan Indra yang dimaksud dengan Lembaga Tertinggi Negara adalah suatu Lembaga yang merupakan manifestasi dari keseluruhan aspirasi rakyat.

Status MPR sebagai lembaga tertinggi negara tersebut dipahami sebagai implikasi dari ketentuan Pasal 1 ayat (2) UUD 1945 yang menyatakan, "Kedaulatan adalah di tangan rakyat, dan dilakukan sepenuhnya oleh Majelis Permusyawaratan Rakyat”. Dengan kata, “...dilakukan sepenuhnya oleh Majelis Permusyawaratan Rakyat", mengandung arti MPR sebagai pemegang kedaulatan (kekuasaan tertinggi) di atas kekuasaan lembaga-lembaga negara yang lainnya. Dalam hubungan ini, bagian Penjelasan UUD 1945 antara lain juga menegaskan, bahwa Majelis Permusyawaratan Rakyat ialah penyelenggara negara yang tertinggi. Majelis ini dianggap sebagai penjelmaan rakyat (Vertretungsorgan des Willens des Staatsvolkes) yang memegang kedaulatan negara. Kemudian dijelaskan pula bahwa oleh karena Majelis Permusyawaratan Rakyat memegang kedaulatan negara, maka kekuasaannya tidak terbatas.

Selanjutnya, ditegaskan pula di dalam bagian Penjelasan bahwa Presiden harus menjalankan haluan negara menurut garis-garis besar yang telah ditetapkan oleh Majelis. Presiden yang diangkat oleh Majelis, tunduk dan bertanggung jawab kepada Majelis. Ia adalah "mandataris" dari Majelis dan wajib menjalankan putusanputusan Majelis. Presiden tidak "neben", akan tetapi “untergeordnet” kepada Majelis.

\footnotetext{
$9 \quad$ Sri Soemantri. (1993). Tentang Lembaga-lembaga Negara Menurut UUD 1945. Bandung: Alumni, hlm. 97.
} 
Di bawah Majelis Permusyawaratan Rakyat, Presiden merupakan penyelenggara pemerintah negara yang tertinggi. Dalam menjalankan pemerintahan negara, kekuasaan dan tanggung jawab adalah di tangan Presiden (concentration of power and responsibility upon the President).

MPR ini nampaknya memiliki kemiripan dengan beberapa lembaga negara di negara lain, seperti dalam sistem ketatanegaraan Amerika Serikat, MPR mirip dengan Kongres atau dalam sistem ketatanegaraan Belanda, mirip dengan 'Staten Generaal'. Namun demikian susunan, kedudukan dan kekuasaannya tidak sama.

Sebagai lembaga tertinggi negara, menurut UUD 1945 MPR, diberi kekuasaankekuasaan (fungsi, tugas dan wewenang) yang sangat strategis seperti yang telah diungkapkan di muka, yakni: 1) Menetapkan UUD (Pasal 3 ayat 2); 2) Menetapkan GarisGaris Besar Haluan Negara (Pasal 3 ayat 2); 3) Memilih Presiden dan Wakil Presiden; (Pasal 6 ayat 2); 4) Mengubah UUD (Pasal 37 ayat 1$)$.

Dalam praktik ketatanegaraan RI di zaman Orde Lama dan Orde Baru, MPR juga mempunyai kekuasaan untuk memberhentikan Presiden dalam masa jabatannya atau manakala Presiden mengundurkan diri dalam masa jabatannya. Dalam sejarah ketatanegaraan RI, MPR pernah memberhentikan Presiden pada masa jabatannya seperti pada zaman Soekarno, Presiden Soeharto, dan Presiden Gus Dur.

MPR juga berwenang untuk mengeluarkan berbagai ketetapan selain Ketetapan tentang Garis-garis Besar Haluan Negara
(GBHN), seperti: ${ }^{10}$

a) Ketetapan MPR No. II/MPR/1978 tentang Pedoman Penghayatan dan Pengamalan Pacasila yang di dalamnya terdapat tekad yang tunggal untuk melaksanakan lima kehendak (Eka Prasetya Panca Karsa);

b) Ketetapan MPRS Nomor XXV/ MPRS/1966 tentang Pembubaran Partai Komunis Indonesia;

c) Ketetapan MPRS RI Nomor XXIX/ MPRS/1966 tentang Pengangkatan Pahlawan Ampera;

d) Ketetapan MPR RI Nomor XI/ MPR/1998 tentang Penyelenggara Negara yang Bersih dan Bebas Korupsi, Kolusi, dan Nepotisme;

e) Ketetapan MPR RI Nomor V/ MPR/2000 tentang Pemantapan Persatuan dan Kesatuan Nasional;

f) Ketetapan MPR RI Nomor VI/MPR/ 2001 tentang Etika Kehidupan Berbangsa;

g) Ketetapan MPR RI Nomor VIII/MPR/ 2001 tentang Rekomendasi Arah Kebijakan Pemberantasan dan Pencegahan Korupsi, Kolusi, dan Nepotisme;

h) Dan lain-lain.

Ketetapan-ketetapan MPR(S) yang di keluarkan sejak tahun 1960-2002 menurut

10 Ketetapan-ketetapan MPR(S) yang dikeluarkan sejak tahun 1960-2002 menurut sifatnya mempunyai ciri-ciri yang berbeda, dan dapat ditemukan beberapa jenis materi yang termuat didalamnya, dengan pengelompokan sebagai berikut: 1. TAP MPRS dan TAP MPR RI yang bersifat mengatur sekaligus memberikan tugas kepada Presiden,; 2. TAP MPRS dan TAP MPR RI yang bersifat penetapan (beschikking); TAP MPRS dan TAP MPR RI yang bersifat mengatur kedalam (interne regelingen); 3. TAP MPRS dan TAP MPR RI yang bersifat deklaratif; 4. TAP MPRS dan TAP MPR RI yang bersifat rekomendasi, dan; 5. TAP MPRS dan TAP MPR RI yang bersifat perundang-undangan. 
sifatnya mempunyai ciri-ciri yang berbeda, dan dapat ditemukan beberapa jenis materi yang termuat di dalamnya, dengan pengelompokan sebagai berikut:

a) TAP MPRS dan TAP MPR RI yang bersifat mengatur sekaligus memberikan tugas kepada Presiden;

b) TAP MPRS dan TAP MPR RI yang bersifat penetapan (beschikking);

c) TAP MPRS dan TAP MPR RI yang bersifat mengatur kedalam (interne regelingen);

d) TAP MPRS dan TAP MPR RI yang bersifat deklaratif;

e) TAP MPRS dan TAP MPR RI yang bersifat rekomendasi; dan

f) TAP MPRS dan TAP MPR RI yang bersifat perundang-undangan.

Dari sekian banyak Ketetapan MPR/S tersebut ada yang sudah dicabut dan ada yang belum. Adapun Ketetapan MPR/S yang belum dicabut antara lain adalah: TAP MPRS Nomor XXV/MPRS/1966 yang me larang ajaran komunisme, leninisme, marxisme, dan PKI organisasi terlarang. Ketetapan MPR No XI/MPR/1998 tentang Penye lenggara Negara yang Bersih dan Bebas Korupsi, Kolusi, dan Nepotisme; TAP MPR Nomor I/MPR/2003 tentang Peninjauan Terhadap Materi dan Status Hukum Ketetapan Majelis Permusyawaratan Rakyat Sementara Dan Ketetapan Majelis Permusyawaratan Rakyat Republik Indonesia Tahun 1960 Sampai Dengan Tahun 2002; Kedua adalah TAP MPR Nomor XVI/MPR/1998 tentang Politik Ekonomi dalam rangka Demokrasi Ekonomi.

Dalam praktik ketatanegaraan, kewenangan MPR tersebut berkembang se- demikian rupa yang ditentukan sendiri oleh MPR. Dalam Ketetapan MPR Nomor I/ MPR/1983 ditemukan Kekuasaan (Tugas dan Wewenang) MPR, sebagai berikut: ${ }^{11}$

1. Menetapkan Undang Undang Dasar;

2. Menetapkan Garis-Garis Besar Haluan Negara;

3. Memilih dan mengangkat Presiden dan Wakil Presiden;

4. Membuat putusan-putusan yang tidak dapat dibatalkan oleh Lembaga Negara yang lain, termasuk penetapan Garis-Garis Besar Haluan Negara yang pelaksanaannya ditugaskan kepada Presiden/Mandataris;

5. Memberikan penjelasan yang bersifat penafsiran terhadap putusan-putusan Majelis;

6. Menyelesaikan pemilihan dan selanjutnya mengangkat Presiden dan Wakil Presiden;

7. Meminta pertanggungjawaban dari Presiden/Mandataris mengenai pelaksanaan Garis-Garis Besar Haluan Negara dan menilai pertanggungjawaban tersebut;

8. Mencabut mandat dan memberhentikan Presiden dalam masa jabatannya apabila Presiden/Mandataris sungguhsungguh melanggar Haluan Negara dan/atau Undang Undang Dasar;

9. Mengubah Undang Undang Dasar;

10. Menetapkan Peraturan Tata Tertib Majelis;

11. Menetapkan Pimpinan Majelis yang dipilih dari dan oleh Anggota;

11 Kekuasaan MPR tersebut tertuang di dalam Pasal 2-4 Ketetapan MPR Nomor I/MPR/1983 tentang Peraturan Tata Tertib MPR. Sebelum TAP MPR tersebut kekuasan MPR juga ditemukan di dalam TAP MPR NO i/mpr/1973 tentang Peraturan Tata Tertib MPR. 
12. Mengambil/memberi keputusan terhadap Anggota yang melanggar sumpah/ janji Anggota;

Menurut Moh. Kusnardi dan Harmaily Ibrahim, kekuasan MPR di luar yang ditetapkan di dalam UUD 1945 sesungguhnya mengalir dari kekuasaan yang ditetapkan di dalam UUD 1945. ${ }^{12}$ Setelah UUD 1945 MPR diubah tetap dipertahankan namun kedudukan dan susunan keanggotaannya, serta kekuasaannya berubah sedemikian rupa secara signifikan. Beberapa perubahan yang terjadi adalah:

1. MPR tidak lagi berkedudukan sebagai lembaga tertinggi negara pemegang kedaulatan rakyat ${ }^{13}$ sebagai implikasi perubahan Pasal 1 ayat (3). Pasal 1 ayat (3) UUD 1945 diubah dan menyatakan, "Kedaulatan berada di tangan rakyat dan dilaksanakan menurut Undang-Undang Dasar”. Jadi Pasal tersebut tidak lagi menyebutkan bahwa kedaulatan rakyat dilaksanakan sepenuhnya oleh Majelis Permusyawaratan. Menurut Ni'matul Huda, hal ini mengisyaratkan secara tegas bahwa MPR tidak lagi sebagai lembaga tertinggi dan tidak lagi sebagai lembaga pemegang kedaulatan rakyat. Pelaksana kedaulatan rakyat kemudian diserahkan kepada setiap lembaga yang mengemban tugas-tugas politik negara

12 Moh. Kusnardi dan Harmaily Ibrahim. (1983). Pengantar Hukum Tata Negara Indonesia. Jakarta: Pusat Sudi Hukum Tata Negara Fakultas Hukum Universitas Indonesia, hlm.192.

13 Jilmly Asshiddiqie. "Struktur Ketatanegaraan Indonesia Setelah Perubahan Keempat UUD 1945". Dikutip pada laman website: http://www.lfip.org/ english/pdf/bali-seminar/Struktur\%20Ketatanegaraan\%20RI\%20-\%20Jimly\%20Asshiddiqie.pdf Diunduh 24 Oktober 20015. (tidak termasuk kekuasaan kehakiman) dan mereka harus tunduk dan bertanggung jawab kepada rakyat. ${ }^{14}$

2. MPR tidak lagi berwenang Menetapkan Garis-garis Besar Haluan Negara (GBHN); Pasal 3 yang dahulu menyatakan: "Majelis Permusyawaratan Rakyat menetapkan Undang-Undang Dasar dan garis-garis besar daripada haluan negara" diubah dan menyatakan: Majelis Permusyawaratan Rakyat berwenang mengubah dan menetapkan UUD". Jadi kata "Garisgaris Besar Haluan Negara” dihapus.

3. MPR tidak lagi mengeluarkan Ketetapan MPR (TAP MPR), kecuali berkenaan dengan menetapkan Wapres menjadi Presiden, memilih Wapres apabila terjadi kekosongan Wapres, atau memilih Presiden dan Wakil Presiden apabila Presiden dan Wakil Presiden mangkat, berhenti, diberhentikan, atau tidak dapat melakukan kewajibannya dalam masa jabatannya secara bersama-sama.

4. MPR tidak lagi sebagai mandataris dari Presiden yang berhak untuk meminta pertanggungjawaban Presiden setiap 5 tahun pada akhir masa jabatannya atau sewaktu-waktu bila Presiden dianggap melanggar Haluan Negara dalam sidang Istimewa.

5. MPR tidak lagi dianggap sebagai Lembaga Negara diberi kekuasaan tak terbatas (super power) karena "kekuasaan ada di tangan rakyat dan dilakukan sepenuhnya oleh MPR" dan MPR

14 Ni'matul Huda. (2007). Lembaga Negara dalam Masa Transisi Demokrasi, Yogyakarta: UII Press, hlm. 96 
adalah "penjelmaan dari seluruh rakyat Indonesia" yang berwenang menetapkan UUD, GBHN, mengangkat Presiden dan Wakil Presiden.

6. MPR tidak lagi berhak memilih Presiden dan wakil Presiden karena kini Presiden dan Wakil Presiden dipilih secara langsung oleh rakyat, kecuali memilih Wapres apabila terjadi kekosongan Wapres dalam masa jabatan, atau memilih Presiden dan Wakil Presiden apabila Presiden dan Wakil Presiden mangkat, berhenti, diberhentikan, atau tidak dapat melakukan kewajibannya dalam masa jabatannya secara bersama-sama.

Dengan adanya perubahan tersebut, maka struktur ketatanegaran Indonesia setelah dan sebelum amendemen, sebagaimana digambarkan pada Gambar 1 dan

\section{Gambar $2 .{ }^{15}$}
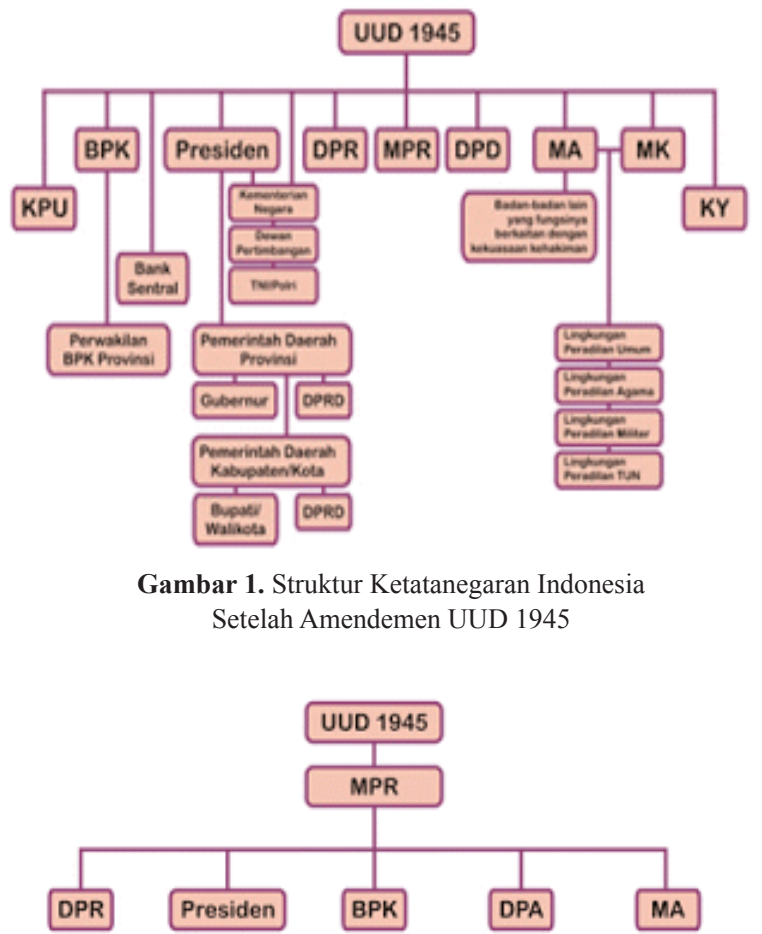

Gambar 2. Struktur Ketatanegaran Indonesia Sebelum Amendemen UUD 1945
Memerhatikan berbagai perubahan UUD 1945 terkait dengan kedudukan dan kekuasaan MPR tersebut, maka tampak bahwa kedudukan dan kekuasaannya MPR telah mengalami degradasi. MPR tidak ubahnya sebagai penumpang pesawat yang duduk di pintu darurat yang akan bekerja sewaktu-waktu manakala terjadi bahaya kecelakaan pesawat. Ia ada, namun seolah-olah tiada. Sebab, dalam keadaan normal, praktis hampir tidak bekerja, sedangkan baru akan bekerja, jika terjadi hal-hal sebagai berikut: a) ada penetapan atau perubahan UUD; b) ada kekosongan Presiden; c) ada kekosongan Wakil Presiden; d) keadaan di mana Presiden dan Wakil Presiden mangkat, berhenti, diberhentikan, atau tidak dapat melakukan kewajibannya dalam masa jabatannya secara bersama-sama; e) ada pelantikan Presiden dan atau Wakil Presiden; dan/atau f) ada usul pemberhentian Presiden dan/atau Wakil Presiden oleh DPR karena berdasarkan Putusan Mahkamah Konstitusi terbukti telah melakukan perbuatan pelanggaran hukum.

Hal-hal tersebut tentu akan sangat langka terjadi kecuali pelantikan Presiden dan Wakil Presiden setiap 5 (lima) tahun sekali. Jika demikian, maka MPR tidak ubahnya sebagai kerakap tumbuh di batu, hidup segan mati tak mau. Akan tetapi keberadaannya sangat vital. Berkaitan dengan hal tersebut, maka perlu dipikirkan agar lembaga yang sangat vital tersebut tidak berada pada posisi antara ada dan tiada.

\section{Upaya Penguatan Kelembagaan}

Ada beberapa hal yang perlu diperhatikan dan dilakukan agar MPR sebagai lembaga negara yang sangat vital tersebut benar- 
benar memiliki wibawa (gezag) dan disegani serta mempunyai kekuasaan riil yang setiap saat dapat dilakukan, yakni sebagai berikut:

\section{Merekonstruksi (meluruskan) pemahaman} (persepsi) tentang kedudukan MPR dalam sistem ketatanegaraan RI

Pandangan selama ini yang menyatakan bahwa setelah amendemen UUD 1945 MPR tidak lagi berkedudukan sebagai lembaga tertinggi negara melainkan sebagai lembaga yang sejajar dengan lembaga-lembaga negara adalah pandangan yang keliru. ${ }^{16}$ Menurut hemat saya hingga saat ini MPR sesungguhnya masih tetap sebagai lembaga tertinggi negara atau setidak-tidaknya kedudukannya tidak sejajar. Hal ini didasarkan pada alasanalsan sebagai berikut:

a. MPR merupakan lembaga negara yang keanggotaannya terdiri atas anggota Dewan Perwakilan Rakyat (DPR) dan angota Dewan Perwakilan Daerah seperti yang dinyatakan di dalam Pasal 2 ayat (1) sebagai berikut:

Majelis Permusyawaratan Rakyat terdiri atas anggota Dewan Perwakilan Rakyat dan anggota Dewan Perwakilan Daerah yang dipilih melalui pemilihan umum dan diatur lebih lanjut dengan undang-undang.

Jadi lembaga yang bernama MPR ini berisi para wakil rakyat dan wakil daerah yang masing-masing membawa mandat dari rakyat karena dipilih langsung oleh rakyat. Dengan kata lain sesungguhnya mereka adalah pelaksana kedaulatan rakyat. Sebagai pelaksa-

16 Setelah amendemen, MPR berkedudukan sebagai lembaga tinggi negara yang setara dengan lembaga tinggi negara lainnya seperti Lembaga Kepresidenan, DPR, DPD, BPK, MA, dan MK. na kedaultan rakyat tentu harus berada di atas kekuasaan lembaga-lembaga negara yang lain. MPR adalah lembaga negara dengan mempergunakan nomenklatur Majelis Permusyawaratan Rakyat bukan Dewan Perwakilan seperti DPR atau Dewan Pertimbangan seperti DPA dahulu.

Hal itu menunjukkan bahwa lembaga ini tersebut diidentikkan lembaga tempat berkumpulnya rakyat untuk bermusyawarah menentukan nasib bangsa dan negara. Karena itulah hanya MPR yang diberi kewenangan menetapkan atau mengubah UUD dan mengangkat Presiden dan/atau Wakil Presiden manakala jabatan itu lowong. MPR lah yang berwenang untuk memberhentikan Presiden yang sekaligus sebagai Kepala Negara. Mengapa tidak diberikan kepada lembaga negara yang lain, karena lembaga inilah satusatunya yang dianggap sebagai representasi rakyat secara lengkap sekaligus merepresentasikan daerah sebagai suatu entitas. Bukan DPR atau DPD atau Presiden dan lain-lain. Karena itu sepatutnya ia diletakkan sebagai lembaga negara yang lebih tinggi dari yang lain. Jangan hanya karena rumusan Pasal 2 UUD 1945 tidak lagi menyatakan, "Kedaulatan adalah di tangan rakyat dan dilakukan sepenuhnya oleh Majelis Permusyawaratan Rakyat," maka seketika kedudukan MPR turun dan sejajar dengan lembaga negara yang lain; Bahkan nomenklatur yang harus dipergunakan bukan MPR mela-inkan MPRD atau Majelis 
Permusya-waratan Rakyat dan Daerah.

Namun tidak berarti dengan menempatkan MPR lebih tinggi kedudukannya dengan negara yang lain lalu dapat bertindak sewenang-wenang melainkan dia harus menjalankan kekuasannya menurut UUD dan tidak pula sistem ketatanegaraan kita menjadi menganut Distribution of Power yang seolah-olah kekuasaan yang diperoleh oleh lembaga lain diturunkan dari kekuasaan MPR. Kebeadaan MPR juga sebagai bagian dari sistem Checks and Balances yang dibangun dalam sistem ketatanegaran.

b. MPR adalah satu-satunya lembaga yang berwenang menetapkan dan mengubah the highest law (Hukum yang tertingi di negara ini) yaitu UUD. Fungsi tersebut tidak dimiliki oleh lembaga lain seperti DPR, DPD, Presiden dan lain-lain. Sebagai lembaga yang berwenang membuat Hukum Dasar (Hukum tertinggi negara ini) maka ia harus diletakkan sebagai lembaga tertinggi negara. Hal ini relevan dengan adagium atau asas hukum yang dikenal dalam ilmu hukum, yaitu Lex Superior derogat lex inferior, artinya hukum yang dibuat oleh kekuasan yang lebih tinggi mempunyai kedudukan yang lebih tinggi pula. Dengan kata lain, hukum yang lebih tinggi dibuat oleh kekuasaan yang lebih tinggi. Karena UUD berkedudukan lebih tingi dari produk hukum yang dibuat oleh lembaga lain, maka seharusnya lembaganya (MPR) berkedudukan lebih tinggi dari lembaga yang lain. Sebagaimana diketahui bahwa menurut ketentuan UUD 1945, UUD dilaksanakan dengan UU, sedangkan UU dibuat oleh DPR bersama Prsiden. Jadi, lembaga yang membuat aturan pelaksanaan UUD harus berkedudukan lebih rendah dari aturan yang dilaksanakan. Jika tidak memberi kedudukan UUD di atas produk yang lain, maka akan bertentangan dengan asas hukum Lex Superior derogat lex inferior tersebut. Dengan demikian, maka MPR harus dipandang kedudukannya lebih tinggi dengan lembaga negara yang lain.

c. Hanya MPR yang boleh memberhentikan Kepala Negara (Presiden). Sebagaimana diketahui, bahwa sebagai Kepala Negara maka Presiden berada pada posisi di atas lembaga negara yang lain termasuk MPR. Akan tetapi meskipun demikian manakala Presiden yang juga Kepala Negara terbukti berdasarkan Putusan Mahkamah Konstitusi (MK) telah melakukan perbuatan pelanggaran hukum berupa pengkhianatan terhadap negara, korupsi, penyuapan, tindak pidana berat lainnya, atau perbuatan tercela; dan/ atau pendapat bahwa Presiden dan/atau Wakil Presiden tidak lagi memenuhi syarat sebagai Presiden dan/atau Wakil Presiden, maka ia dapat diberhentikan. Lembaga yang berwenang memberhentikannya adalah MPR. Selain itu, MPR dapat juga tidak memberhentikan meskipun ternyata Presiden telah terbukti melakukan pelanggaran seperti yang disebutkan di dalam UUD 
dengan Putusan MK. Berdasarkan hal tersebut, maka sepatutnya MPR berkedudukan lebih tinggi dibandingkan dengan lembaga negara yang lain termasuk Presiden sebagai Kepala Negara.

d. Hanya MPR yang dapat mengangkat Wakil Presiden menjadi Presiden manakala jabatan Presiden lowong dan hanya MPR yang diserahi kekuasaan untuk mengangkat Presiden dan Wakil Presiden yang baru manakala Presiden dan Wakil Presiden sebelumnya berhalangan tetap karena tidak mampu lagi menjalankan tugas-tugasnya sebagai Presiden dan/atau Wakil Presiden meninggal dunia, atau diberhentikan atau mengundurkan diri.

e. Presiden dan/atau Wakil Presiden dilantik oleh MPR. Sesuai bunyi ketentuan Pasal 9 UUD 1945, sebelum memangku jabatannya, Presiden dan Wakil Presiden harus bersumpah menurut agama, atau berjanji dengan sungguh-sungguh di hadapan Majelis Permusyawaratan Rakyat atau Dewan Perwakilan Rakyat. Jika Majelis Permusyawaratan Rakyat atau Dewan Perwakilan Rakyat tidak dapat mengadakan sidang, Presiden dan Wakil Presiden bersumpah menurut agama, atau berjanji dengan sungguh-sungguh di hadapan pimpinan Majelis Permusyawaratan Rakyat dengan disaksikan oleh pimpinan Mahkamah Agung. Berdasarkan hal tersebut, maka sesungguhnya MPR merupakan lembaga yang secara fungsional kedudukannya superior di hadapan lembaga negara yang lain.

\section{Meminta dan menilai kinerja lembaga- lembaga negara}

Upaya berikutnya yang perlu dilakukan untuk memperkuat kelembagaan MPR adalah MPR hendaknya berhak untuk meminta dan menilai kinerja lembaga-lembaga negara. Hal ini sebagai konsekuensi MPR sebagai lembaga yang berkedudukan lebih superior dari yang lain, sebagaimana dijelaskan di muka. Adalah wajar pula bila para wakil rakyat dan wakil daerah yang dipilih oleh rakyat langsung diberi kewenangan untuk mendengar dan menilai laporan pertanggungjawaban kinerja masing-masing lembaga negara yang selama ini belum pernah dilakukan karena tidak jelas mekanismenya.

Dalam negara yang demokratis di mana rakyat berhak menentukan kebijakan (kekuasaan), melaksanakan kebijakan (kekuasaan) dan mengawasi kebijakan (kekuasaan) maka sudah tentu rakyat melalui wakilnya berhak mendengar dan menilai kinerja dari masingmasing lembaga negara sebagai bentuk pertanggungjawaban atas kinerja atau pelaksanaan tugas yang diberikan kepadanya melalui UUD. Selama ini rakyat tidak pernah mengetahui bagaimana lembaga-lembaga negara yang konon juga melaksanakan amanat penderitaan rakyat telah melaksanakan tangungjawabnya masing-masing.

Dalam kaitannya dengan ini, alangkah baiknya masing-masing menyampaikan laporan pertangungjawaban (progress report) setiap tahunnya kepada rakyat melalui wakilnya yang duduk di MPR. Sudah tentu DPR dan DPD juga berkewajiban menyampaikan laporan tersebut kepada MPR. MPR harus dijadikan media untuk mendengar 
laporan pertanggungjawaban pelaksanaan tugas kepada rakyat dalam sidang MPR yang dilaksanakan setiap tahunnya. Hal ini sangat dimungkinkan, sebab dalam Pasal 2 ayat (2) UUD 1945 Majelis Permusyawaratan Rakyat bersidang sedikitnya sekali dalam lima tahun di ibu kota Negara. Dengan frase, "sedikitnya dalam lima tahun" mengandung arti dimungkinkan sekali MPR bersidang lebih dari sekali dalam lima tahun seperti setiap tahun. Namun demikian, harus dicegah agar sidang tahunan MPR tidak dimaksudkan untuk menilai dan apalagi untuk meminta pertanggungjawaban lembaga-lembaga negara oleh MPR atau sebagai sarana untuk menjatuhkan lembaga negara tertentu.

\section{Berwenang untuk mengubah dan me-} ngontrol produk hukum yang dikeluarkan oleh lembaga-lembaga yang melaksanakan UUD

MPR hendaknya diberikan perluasan kewenangan yakni untuk mengubah dan mengontrol produk hukum yang dikeluarkan oleh lembaga-lembaga yang melaksanakan UUD. Artinya, bahwa jika ada produk hukum untuk melaksanakan UUD bertentangan dengan kemauan politik MPR atau bertentangan dengan isi UUD, maka hendaknya kembali kepada pembuat UUD yang akan meluruskan. Oleh karena itu, setiap produk UU jika bertentangan dengan kemauan UUD maka semestinya MPR dapat menyatakannya dalam Ketetapan MPR sebagaimana juga Ketetapan MPR.

Hal ini merupakan konsekuensi logis juga atas kedudukan MPR yang lebih tinggi dari lembaga negara yang lain. Dengan demikian, maka produk MK yang selama ini merupakan produk hukum yang menafsirkan UUD seharusnya dapat dikontrol oleh MPR. Putusan MK yang dianggap menyimpang dari UUD, seharusnya dapat dinyatakan bertentangan dengan kemauan UUD oleh MPR. Hal ini merupakan konsekuensi logis dari fungsi MPR sebagai pembuat UUD. Jadi lembaga yang tahu persis maksud dari UUD adalah lembaga pembuatnya. Sedangkan MK hanya menafsirkan, yang namanya menafsirkan, ia bisa benar, bisa juga salah. Sebagai contoh, putusan MK terkait kewenangan mengadili hasil Pemilihan Umum Kepala Daerah. Dahulu MK dinyatakan berwenang, namun saat ini, tidak lagi berwenang berdasarkan Putusan MK. Apakah hal tersebut benar atau tidak menurut kemauan UUD, maka perlu dinilai oleh pembuat UUD itu sendiri, yakni MPR. Untuk kepentingan ini, sudah barang tentu diperlukan perubahan terhadap UUD.

Kewenangan MPR untuk menilai produk hukum (legislative review) yang dikeluarkan oleh lembaga negara yang lain sebagai pelaksanaan UUD juga merupakan konsekuensi logis dari kewenangan MPR sebagai pembentuk UUD. Kalau MPR melihat adanya penyimpangan atas pelaksanaan UUD, maka tentu MPR berhak untuk menilainya.

\section{Diberikan kewenangan untuk membuat GBHN}

Satu hal yang dihilangkan dari kewenangan MPR adalah membuat/menetapkan GBHN. Dalam UUD 1945 sebelum amendemen, dinyatakan secara tegas bahwa tugas MPR adalah menetapkan GBHN (Pasal 3 ayat 1). Menghilangkan fungsi tersebut menimbul- 
kan dampak tidak adanya kontrol dari rakyat melalui wakilnya tentang kearah mana pembangunan bangsa dilaksanakan. Sebagaimana diketahui, bahwa GBHN memuat pola umum pembangunan nasional, yaitu rangkaian program-program pembangunan yang menyeluruh, terarah dan terpadu, yang berlangsung secara terus-menerus.

Rangkaian program-program pembangunan yang terus menerus itu dimaksudkan untuk mewujudkan tujuan nasional seperti termuat dalam Pembukaan UUD'45. Program-program itu pada hakikatnya adalah pernyataan kehendak rakyat tentang masyarakat yang dicita-citakan. Dapat juga dikatakan bahwa GBHN tidak lain adalah arah dan strategi pembangunan nasional untuk mewujudkan masyarakat adil dan makmur berdasarkan Pancasila dan UUD 1945. GBHN menggariskan kebijaksanaan, langkah dan sasaran-sasaran untuk mewujudkan cita-cita tersebut.

Jadi, fungsi GBHN adalah, sebagai haluan ke arah mana pembangunan nasional ditujukan dan sebagai alat untuk menentukan masa depan negara. Dalam masa Orde Baru, hampir setiap 5 tahun GBHN dibuat boleh MPR. Dalam penjelasan UUD 1945 dahulu dinyatakan bahwa mengingat dinamika masyarakat, sekali dalam 5 tahun Majelis memerhatikan segala yang terjadi dan segala aliran-aliran pada waktu itu dan menentukan haluan-haluan apa yang hendaknya dipakai untuk di kemudian hari. Diberikannya kewenangan untuk menetapkan GBHN sebagai implementasi UUD, sesungguhnya juga merupakan konsekuensi logis dari kewenangan MPR membuat UUD. Jika MPR berhak menetapkan UUD, maka tentu
MPR juga berhak menentukan GBHN sebagai petunjuk dalam melaksanakan kehendak UUD.

\section{PENUTUP}

Dari uraian tersebut di atas, dapat disimpulkan, bahwa keberadaan MPR dalam sistem ketatanegaraan RI memiliki fungsi yang sangat vital. Namun demikian, diperlukan upaya penataan kembali tentang kedudukan, tugas dan wewenangnya, agar keberadaannya lebih berwibawa dan lebih bermanfaat. Kondisi saat ini, MPR adalah ibarat penumpang pesawat yang duduk di pinggir pintu darurat, yang hanya sewaktu-waktu saja diperlukan, yakni hanya manakala akan terjadi kecelakaan pesawat.

Hendaknya MPR diperkuat eksistensinya dengan upaya-upaya sebagai berikut: 1) Merekonstruksi (meluruskan) pemahaman (persepsi) tentang kedudukan MPR dalam sistem ketatanegaraan RI; 2) MPR hendaknya berhak untuk meminta dan menilai kinerja lembaga-lembaga negara; 3) MPR juga hendaknya diberi kewenangan untuk menilai produk hukum yang dikeluarkan oleh lembaga-lembaga yang melaksanakan UUD apakah sesuai dengan kemauan UUD NRI 1945; dan 4) MPR hendaknya diberikan kewenangan untuk membuat GBHN. Tentunya, untuk melaksanakan hal-hal tersebut, jika perlu segera diadakan amendemen UUD 1945 yang kelima.

\section{BIBLIOGRAFI}

Eko Riyadi. (2012). "Reposisi Majelis Permusyawaratan Rakyat (MPR) dan Implikasinya Terhadap Kedudukan Tap MPR/S Pasca Amendemen UUD 
1945". Majalah Supremasi Hukum,

Vol. 1, No. 1, Juni 2012, Fakultas Syari'ah dan Hukum, UIN Sunan Kalijaga.

Jimly Asshidiqie. (2005). Format Kelembagaan Negara dan Pergeseran Kekuasaan dalam UUD 1945. Yogyakarta: FH UII Press.

. (2006). Sengketa Kewenangan Konstitusional Lembaga $\mathrm{Ne}$ gara. Jakarta: KonPress.

Moh. Kusnardi dan Harmaily Ibrahim. (1983). Pengantar Hukum Tata Negara Indonesia. Jakarta: Pusat Studi Hukum Tata Negara Fakultas Hukum Universitas Indonesia.

Ni'matul Huda. (2007). Lembaga Negara dalam Masa Transisi Demokrasi, Yogyakarta: UII Press.
Sri Soemantri. (1993). Tentang Lembagalembaga Negara Menurut UUD 1945. Bandung: Alumni.

\section{Sumber lainnya:}

Jimly Asshidiqie. Struktur Ketatanegaraan Indonesia Setelah Perubahan Keempat UUD Tahun 1945. Makalah disampaikan pada Seminar Pembangunan Hukum Nasional VIII. Diselenggarakan oleh Badan Pembinaan Hukum Nasional Departemen Kehakiman dan Hak Asasi Manusia RI Denpasar, 1418 Juli 2003.

Warsito. "Kedudukan MPR", dikutip pada laman website: http://warsito-bicara. blogspot.co.id/2008/09/kedudukanmpr.html, Diunduh 5 Nopember 2015. 